\title{
ASSESSMENT OF FACTORS EFFECTING HEALTHY MAXILLARY SINUS VOLUMES WITH CBCT
}

\section{SAĞLIKLI MAKSİLLER SİNÜSLERİN HACMİNİ ETKİLEYEN FAKTÖRLERİN KIBT İLE DEĞERLENDİRİLMESİ}

\author{
Dr. Öğr. Üyesi Özlem OKUMUŞ*
}

Dr. Öğr. Üyesi Zeliha Zuhal YURDABAKAN*

\author{
Makale Kodu/Article code: 4811 \\ Makale Gönderilme tarihi: 13.01 .2021 \\ Kabul Tarihi: 12.03.2021 \\ DOI : $10.17567 /$ ataunidfd.947003
}

Özlem Okumuş: ORCID ID: 0000-0002-5590-2357

Zeliha Zuhal Yurdabakan: ORCID ID: 0000-0002-0591-4464

\section{ABSTRACT}

Aim: The purpose of this study was to investigate the factors influencing the volume of healthy maxillary sinuses by cone beam computed tomography (CBCT).

Material and Methods: The maxillary sinus volumes of healthy and entirely visible on the CBCT scan of patients over 18 years of age were evaluated bilaterally using NNT Viewer volumetric software (CeflaGroup, Verona, Italy). The images with pathologic changes in one or both maxillary sinuses were excluded. The study included 200 healthy maxillary sinuses of 100 patients (65 female and 35 male) aged between 19 to 85 years with a mean age of $44.13 \pm 16.36$ years. The status of the dentition in the posterior maxilla in regards to the maxillary sinus was classified as dentate, partially dentate and edentulous. Differences in volume based on gender, age, sinus side, and dental status were analyzed statistically.

Results: There were $104(52 \%)$ dentate sinuses and 76 (38\%) partially dentate and $20(10 \%)$ edentulous sinuses. Males had significantly larger maxillary sinus volumes compared to females $(p<0.05)$. There was an inverse and rather weak $(15 \%)$ but statistically significant relationship between age and sinus volume $(p<0.05)$. There was no difference in volume between the right and left sinuses and dental status showed no differences in sinus volume $(p<0.05)$

Conclusion: Gender and age influence healthy maxillary sinus volume, while sinus side and dental status do not. Although it has been reported that the maxillary sinus volume increases throughout life after removal of the posterior teeth in the upper jaw, we found in our study that tooth loss was not associated with the ongoing pneumatization of the maxillary sinus. To validate this finding, there is a need for prospective studies comparing sinus volumes using standard time intervals before and after tooth extraction in the posterior maxilla.

Key words: cone beam computed tomography; maxillary sinus; paranasal sinuses; volume

Öz

Amaç: Bu çalışmanın amacı konik ışını biligisayarlı tomografi (KIBT) ile sağlıkı maksiller sinüslerin hacmini etkileyen faktörleri araştırmaktır.

Gereç ve yöntem: 18 yaşın üzerindeki hastalara ait KIBT taramasında sağlıklı ve tamamen görülebilen maksiller sinüslerin hacimleri, NNT Viewer programı (CeflaGroup, Verona, İtalya) kullanılarak bilateral olarak değerlendirildi. Maksiller sinüslerin birinde veya her ikisinde patolojik değişiklik olan görüntüler çalışmaya dahil edilmedi. Çalışmaya yaş ortalaması $44.13 \pm 16.36$ olan 19-85 yaşları arasındaki 100 hastaya ait (65 kadın ve 35 erkek) 200 sağlıklı maksiller sinüs dahil edildi. Maksiller sinüs ile ilişkili posterior maksilladaki dişlerin durumu dişli, parsiyel dişli ve dişsiz olarak sınıflandırıldı. Cinsiyete, yaşa, sağ-sol maksiller sinüse ve dental duruma göre hacim farklılıkları istatistiksel olarak analiz edildi.

Bulgular: Dişlerin durumuna göre sınıflandırmada 104'ü (\%52) dişli, 76'sı (\%38) parsiyel dişli ve 20'si (\%10) dişsizdir. Erkeklerde kadınlara göre maksiller sinüs hacimleri anlamlı olarak daha yüksek olarak bulunmuştur $(p<0.05)$. Yaş ve sinüs hacmi arasında ters ve oldukça zayıf $(\% 15)$ ancak istatistiksel olarak anlamlı bir ilişki vardır $(p<0.05)$. Sağ-sol maksiller sinüs hacmi ve dental duruma göre maksiller sinüs hacmi arasında istatistiksel olarak anlamlı farklılık gözlenmemiştir ( $p>0.05)$.

Sonuç: Cinsiyet ve yaş sağlıklı maksiller sinüs hacmini etkilerken, sağ-sol sinüs tarafı ve diş durumu etkilememiş̧ir. Üst çenede posterior dişlerin çekiminden sonra maksiller sinüs hacminin yaşam boyunca arttığı bildirilmiş olsa da çalışmamızda diş kaybının maksiller sinüsün pnömatizasyonu ile ilişkili olmadığı bulundu. Bu bulguyu doğrulamak için posterior maksillada diş çekimi öncesi ve sonrası standart zaman aralıklarında sinüs hacimlerini karşılaştıran prospektif çalışmalara ihtiyaç vardır.

Anahtar kelimeler: konik ışınlı bilgisayarlı tomografi; maksiller sinüs; paranazal sinüs; hacim

*Altınbas University Faculty of Dentistry, Department of Dentomaxillofacial Radiology, Istanbul

Kaynakça Bilgisi: Okumuş Ö, Yurdabakan ZZ. Sağlıkı maksiller sinüslerin hacmini etkileyen faktörlerin DVT ile değerlendirilmesi. Atatürk Üniv Diş Hek Fak Derg 2021; 31: 325-30.

Citation Information: Okumus O, Yurdabakan ZZ. Assessment of factors effecting healthy maxillary sinus volumes with CBCT. J Dent Fac Atatürk Uni 2021; 31: 325-30. 


\section{INTRODUCTION}

Paranasal sinuses are the air-filled cavities of the maxillofacial complex including the maxillary, frontal, sphenoid and ethmoid sinuses. These sinuses have many functions such as increasing resonance of the voice, heating and humidifying the inhaled air, absorption of traumas to the head and face, lightening the weight of the skull and facial bones, mucus secretion, adjusting the internal and external atmospheric pressure, and enlarging the face. ${ }^{1}$

The maxillary sinus is the largest of the paranasal sinuses and has a pyramidal shape. It is of great importance for dentists as it is close to related anatomical structures. ${ }^{2}$

The sinus is full of fluid until birth and its volume at birth is $6-8 \mathrm{~cm}^{3} .^{3}$ The volume of maxillary sinus reaches its adult size around the ages of 14-18. The mean volume of the maxillary sinus is approximately $15 \mathrm{~cm}^{3}$ in an adult. ${ }^{4}$

Pneumatization of the maxillary sinus is a continuous physiological process. The paranasal sinuses increase in volume and fill with air during growth, and extraction of the maxillary posterior teeth and associated alveolar crest resorption are important factors affecting pneumatization. While the maxillary sinus is affected by an infection caused by the maxillary posterior teeth, the pathological formation in the maxillary sinus also affects the teeth. ${ }^{5}$

It is important to have accurate knowledge about the maxillary sinus anatomy in preventing the possibility of the complications of the maxillofacial surgeries, in the evaluation of the this area before implant threapy, in determining the amount of graft to be used before sinus lifting operation, and in orthodontic mini implant threapy. ${ }^{2}$ Morphometric analysis of the maxillary sinus is required to determine which surgical technique will be used during the operations at maxil- lofacial region and to avoid injury to the structures in this area. In addition, maxillary sinuses can be evaluated in determining gender in cases where the whole skeleton is not available in forensic medicine. ${ }^{6}$

Panoramic and lateral cephalometric radiography, computed tomography (CT), cone beam computed tomography (CBCT) and magnetic resonance imaging (MRI) techniques have been used for measuring maxillary sinus volume in the literature. ${ }^{1}, 7$ Since the diagnostic values of twodimensional imaging methods are limited and insufficient in terms of imaging pathological formations and anatomical variations in the sinuses, in recent years, СВCT has become useful threedimensional diagnostic and scientific tool. The data acquired by CBCT presents coronal, sagittal, and axial sections and provides multiplanar images with uniform low magnification. Although CT is a widely used threedimensional imaging technique, CBCT is preferred because of its low cost, high resolution, lower radiation dose and better image quality. These advantages of CBCT help the clinician to evaluate the maxillary sinuses accurately. ${ }^{8}$

Since the literatures on the morphometry of maxillary sinus volume used by CBCT are limited, we aimed to examine the effects of gender, age, sinus side and dental status on the volume of healthy maxillary sinuses by CBCT in this study retrospectively.

\section{MATERIALS AND METHODS}

This study was approved by the Clinical Research Ethical Committee of Altınbaş University (approval number: 2020/24). In this retrospective study, the study group consisted of the records of the patients who had $x$-rays with various indications in the CBCT archive of Altınbaş University Faculty of Dentistry, Department of Dentomaxillofacial Radiology. Written consent forms are routinely obtained from patients before $\mathrm{CBCT}$ examinations.

In this study, inclusion criteria was $\mathrm{CBCT}$ records of patients over 18 years of age with healthy maxillary sinuses. Poor quality images and pathological changes such as mucosal thickening, polypoid lesion, complete opacification of the sinus, cyst, foreign body, bone destruction, developmental anomalies in one or both maxillary sinuses were excluded. The study was consisted of a CBCT scan of 200 healthy maxillary sinuses of 100 patients (65 females and 35 males) between the ages of 19 to 85 years with a mean age of $44.13 \pm 16.36$.

$\mathrm{CBCT}$ images of all patients were acquired with NewTom Vgi evo (CeflaGroup, Verona, Italy). The device was set for 1-32 $\mathrm{mA}$ and $110 \mathrm{kV}$ with a single 360 degree rotation created images with a voxel size of $0.3 \mathrm{~mm}$. Volumes of healthy and fully visible maxillary sinuses in CBCT scan were performed bilaterally with the "high speed" mode of the volumetric software feature of the NNT Viewer (CeflaGroup, Verona, Italy) program. In the measurement of the maxillary sinus volume, the center of the maxillary sinus in the axial plane was determined first, and then the maxillary sinus was selected with the "rectangular frame" feature of the 
volumetric software program. The threshold value was set at 400 in order to contain the largest number of voxels within the maxillary sinus air cavity and to exclude as much of the voxels within the air cavities of surrounding structures, including the nasal cavity. The default threshold was a simulated Hounsfield unit (HU) of 400, and all voxels below this threshold were included in the volume calculation. The sinus volume was created in $3 D$ and the sinus volume was calculated and recorded as $\mathrm{cm}^{3}$ (Figure 1). Radiological images were evaluated on a 22" high image quality Barco medical monitor in order to provide an effective evaluation by Oral and Maxillofacial Radiology specialists (Ö. O and Z. Z. Y.). The left and right maxillary sinus volumes of the $20 \%$ of the individuals were measured separately by two observers to evaluate inter-observer compliance. Intra-class correlation coefficient was achieved as 0.99 .

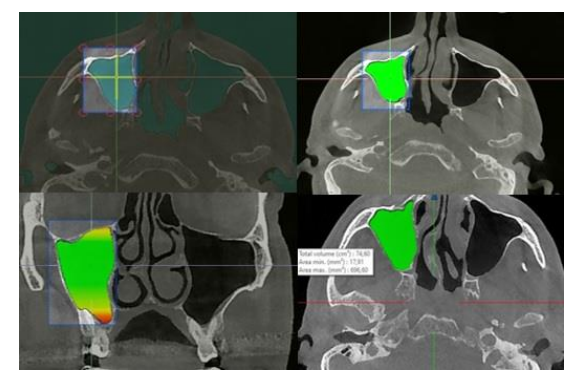

Figure 1. Measurement of maxillary sinus volume on axial and coronal sections of CBCT scan.

To assess the factors affecting the healthy maxillary sinuses volume, the dental status at the posterior maxilla was classified as dentate (in the presence of first, second premolar and molar teeth), partially dentate (tooth loss $\geq 1$ ), and edentulous. The third molars were excluded from the study.

\section{Statistical analysis}

Statistical differences in maxillary sinus volume were analyzed according to gender, age, sinus side and dental status.

SPSS Statistics 22 (SPSS IBM, Turkey) software program was used for all statistical analyzes. The conformity of the parameters to the normal distribution was analyzed using the Shapiro Wilks test and the parameters were found to conform for the normal distribution. Besides the descriptive statistical methods (mean, standard deviation, frequency), the one-way analysis of variance (ANOVA) test was used to compare the quantitative data and the parameters according to the dental status; Student $t$ test was used to compare age group, gender and right-left maxillary sinus. Pearson's correlation analysis was used to assess the relationship between sinus volume and age. $\mathrm{P}$ values $<0.05$ were considered as significant statistically.

\section{RESULTS}

This study was carried out on 200 maxillary sinuses of 100 cases, 35 (35\%) male and 65 (65\%) female between 19 and 85 years old and the mean age of all individuals was $44.13 \pm 16.36$.

When the relationship between maxillary sinus volume and gender was investigated, the mean maxillary sinus volume of men $(61.46 \pm 20.73)$ was found to be higher than women (49.96 \pm 19.66$)$ significantly ( $p: 0.000 ; p<0.05)$. The median age of the patients included in the study was 40 years old, and there was no statistically significant difference between the mean maxillary sinus volume of the cases below 40 and over 40 years old ( $p>0.05$ ). There was no statistically significant difference between the mean right and left maxillary sinuse volume ( $p>0.05$ ). Difference between the mean maxillary sinus volume in terms of dental status was not statistically significant ( $p>0.05)$ (Table 1$)$.

When the correlation between age and the maxillary sinus volume were evaluated, there was an inverse, very weak (15.1\%) but statistically significant relationship between them ( $\mathrm{p}: 0.033$; $p<0.05$ ) (Table 2).

Table 1. Evaluation of parameters affecting maxillary sinus volume

\begin{tabular}{|c|c|c|}
\hline & n (\%) & Sinus volume \\
\hline & & Mean \pm SD \\
\hline Gender & $70(\% 35)$ & $61.46 \pm 20.73$ \\
\hline Female & $130(\% 65)$ & $49.96 \pm 19.66$ \\
\hline${ }^{1 p} p$ & & $0.000 *$ \\
\hline Age & $100(\% 50)$ & $55.44 \pm 20.91$ \\
\hline$>40$ & $100(\% 50)$ & $52.52 \pm 20.55$ \\
\hline${ }^{1 p}$ & & 0.320 \\
\hline Right & $100(\% 50)$ & $53.51 \pm 20.58$ \\
\hline Left & $100(\% 50)$ & $54.46 \pm 20.98$ \\
\hline${ }^{1 p}$ & & 0.745 \\
\hline \multicolumn{3}{|l|}{ Dental Status } \\
\hline Dentate & $104(\% 52)$ & $54.01 \pm 20.35$ \\
\hline Edentulous & $20(\% 10)$ & $58.27 \pm 21.08$ \\
\hline Partially dentate & $76(\% 38)$ & $52.82 \pm 21.28$ \\
\hline${ }^{2} p$ & & 0.581 \\
\hline
\end{tabular}

Table 2. Maxillary sinus volume correlation with age

\begin{tabular}{lc}
\hline & Age-Sinus Volume \\
\hline \hline $\mathrm{R}$ & -0.151 \\
$\mathrm{P}$ & $0.033^{*}$ \\
\hline Pearson's correlation analysis & ${ }^{*} p<0.05$
\end{tabular}




\section{DISCUSSION}

The maxillary sinuses are the largest of the paranasal sinuses in volume and are of great importance due to their anatomical proximity to dental structures, and they can vary in volume, shape and size. A good knowledge of the normal volumes and anatomy of the maxillary sinuses is extremely important for dentistry in dental implant applications in the posterior region of the maxilla, and the spread of infection. ${ }^{1}$ In this study, the maxillary sinus volumes of male and female groups of different ages were measured bilaterally, and the differences between individuals were evaluated by assessing the tooth loss in the right-left maxilla posterior region.

In the literature, different imaging methods (CT, MRI and CBCT), various software programs, cadaver studies and volume measurements on the image sections have been used to evaluate the pneumatization in the paranasal sinuses, and accordingly different results have been obtained. ${ }^{2,5}$

Although the difference between the left and right maxillary sinus volumes of the same individuals in most studies is not significant statistically, ${ }^{5,9,11}$ this was not valid for individuals with nasal septum deviation. ${ }^{12}$ In this study, the mean right maxillary sinus volume was $53.51 \pm 20.58 \mathrm{~cm}^{3}$, the mean left maxillary sinus volume was $54.46 \pm 20.98 \mathrm{~cm}^{3}$, and there was no significant difference between them.

In some studies, there were differences in the volume of maxillary sinus between genders, and the volume of the maxillary sinus was higher in men. ${ }^{11,13,14}$ Similarly, Rani et al. ${ }^{15}$ conducted a study with MRI and evaluated the correlation between age, gender and maxillary sinus volume by morphometric analysis of the maxillary sinus. They stated that the maxillary sinus volume was higher in men than women statistically. However, in some studies, there was no significant difference between gender and maxillary sinus volume. ${ }^{9,16-18}$ The different results may be due to the differences in female-male ratio, race, and in sinus volume calculation methods. In this study, the mean maxillary sinus volume was $61.46 \pm 20.73 \mathrm{~cm}^{3}$ in men and $49.96 \pm 19.66 \mathrm{~cm}^{3}$ in women, and the difference between them was statistically significant. However, in our study, the sinus volumes were higher than the literature findings. The reason of this result might be due to the "high speed" mode used in our study for volume calculation.

There are many studies evaluating the age related changes on the maxillary sinus volume.
Emirzeoğlu and Şahin ${ }^{14}$ reported a negative correlation between age and volume in their study on 77 patients over 18 years of age. Ariji et al. ${ }^{9}$ examined the age related changes on maxillary sinus volume of 115 CT images. They reported that the maxillary sinus volume enlarged until the age of 20 and then there was a gradual decrease in maxillary sinus volume. Karakaş and Kavaklı19 ${ }^{19}$ investigated age related changes on mastoid cell pneumatization and paranasal sinus volumes of 91 patients between the age of 5-55 years old by $\mathrm{CT}$ and reported that maxillary sinus volume increases with age significantly. Bornstein et al. ${ }^{11}$ reported that the median age was 24.3 , and the maxillary sinus volume was significantly higher in individuals below the median age compared to those above the median age in a study on healthy maxillary sinus by CBCT. Kalabalik and Tarım Ertaş ${ }^{20}$ analyzed the images of 252 patients between the ages of 12-85 with missing maxillary premolar and molar teeth by $\mathrm{CBCT}$ and reported that there was a negative correlation between age and maxillary sinus volume. Sahlstrand-Johnson and Jannert ${ }^{10}$ did not observe a correlation with age and sinus volume in a study of 60 patients over 18 years of age by using CT. In another study of investigating age related changes on paranasal sinus volumes of 60 patients aged 18 to 63 years, there was no correlation between age and sinus volume. ${ }^{21}$ Güleç et al. ${ }^{5}$ also reported that there was no correlation between age and maxillary sinus volume on 133 CBCT images of patients aged 8-51 years. In the present study, the median age was 40 and there was no difference between the mean maxillary sinus volume of the cases below and over 40 years significantly. When the relation between sinus volume and age was examined, there was an inverse, very weak $(15.1 \%)$ but statistically significant relationship between them. The differences between the results of this study and other studies might be due to the different age distributions of the study groups and the dental status of the patients.

Different dental status of the patients should also be examined in the right and left maxilla posterior region. Bornstein et al. ${ }^{11}$ collected the partially dentate and edentulous cases in the same group and compared them with dentate groups in the study evaluating the healthy maxillary sinus volume with $\mathrm{CBCT}$, and reported that there was no difference between the groups in terms of maxillary sinus volume significantly. Ariji et al. ${ }^{22}$ reported that tooth loss had no effect on pneumatization in the study with CT. Schriber et al. ${ }^{23}$ reported that there was no difference 
between maxillary sinus volumes on dentate and edentulous patients in the study comparing maxillary sinus volumes on dentate and edentulous patients by СВCT. In our study, the dental status in the posterior maxilla was classified as dentate, partially dentate and edentulous and similar to the literature findings mentioned above, there was no statistically significant difference between the dental status and the mean maxillary sinus volume.

In addition, studies on different races and geographies have observed that racial and geographical factors can change the maxillary sinus volume. ${ }^{24,25}$ It was reported that the average maxillary sinus volume of Japanese people was higher than other races in a study with CT (the average volume of the right maxillary sinus: $23.6 \mathrm{~cm}^{3}$, the average volume of the left maxillary sinus: $\left.20.9 \mathrm{~cm}^{3}\right) \cdot{ }^{24}$ In a study on European and Zulu cadavers divided by race and gender, it was reported that the mean maxillary sinus volumes of the two races were different from each other significantly (European race: the avarage volume of right maxillary sinus: $16.39 \mathrm{~cm}^{3}$, the avarage volume of left maxillary sinus: $16.42 \mathrm{~cm}^{3}$; for Zulu race: the avarage volume of right maxillary sinus: $11.13 \mathrm{~cm}^{3}$, the avarage volume of left maxillary sinus: $\left.10.99 \mathrm{~cm}^{3}\right) .^{25}$

In another study evaluating the maxillary sinus volume in different craniofacial patterns, it was reported that maxillary sinus volume is significantly larger in skeletal class II than in skeletal class III group and also the volume of the maxillary sinus was higher in men. ${ }^{26}$ In a study evaluating maxillary sinus changes after Le Fort I osteotomy, a decrease in maxillary sinus volume and an increase in sinus membrane thickness were observed. They concluded that Le Fort I osteotomy affected the volume and thickness of the maxillary sinuses. ${ }^{27}$

\section{CONCLUSION}

The result of this retrospective study according to the our findings:

- It is possible to view the maxillary sinus in 3D and calculate the volume with $\mathrm{CBCT}$ which has the advantage of low radiation dose.

- Average maxillary sinus volume of men was higher than women significantly.

- Difference between the avarage volume of right and left maxillary sinuses was not significant statistically.

- There was a statistically significant but reversed and quite weak correlation between age and maxillary sinus volume.
- Difference between dental status and maxillary sinus volume was not significant statistically. Although it has been stated that the maxillary sinus expanded throughout life after missing of the posterior teeth in the upper jaw, in our study, it was concluded that tooth loss was not associated with pneumatization of the maxillary sinus. In future, studies comparing sinus volumes at standard time intervals before and after tooth removal in the posterior maxilla are required to support our findings.

Our results are higher than the literature findings, and more comparative studies are needed using the "high resolution" mode.

\section{Acknowledgements \\ The authors declare that there were no other contributors involved in this work.}

\section{REFERENCES}

1. Aksoy S, Orhan K. Paranazal Sinüs Hacimlerinin Değerlendirilmesi. Turkiye Klinikleri J Oral Maxillofac Radiol-Special Topics 2017;3:184-8.

2. Aktuna Belgin C, Colak M, Adiguzel O, Akkus Z, Orhan $\mathrm{K}$. Three-dimensional evaluation of maxillary sinus volume in different age and sex groups using CBCT. Eur Arch Otorhinolaryngol 2019;276:1493-9.

3. Apuhan T, Yıldırım YS, Özaslan $H$. The developmental relation between adenoid tissue and paranasal sinus volumes in 3-dimensional computed tomography assessment. Otolaryngol Head Neck Surg 2011;144:964-71.

4. Park IH, Song JS, Choi H, Kim TH, Hoon S, Lee SH, Lee HM. Volumetric study in the development of paranasal sinuses by $\mathrm{CT}$ imaging in Asian: a pilot study. Int J Pediatr Otorhinolaryngol 2010;74: 1347-50.

5. Gulec M, Tassoker M, Magat G, Lale B, Ozcan S, Orhan K. Three-dimensional Volumetric Analysis of the Maxillary Sinus: A Cone-Beam Computed Tomography Study. Folia Morphol (Warsz) 2020; 79: 557-62.

6. Teke HY, Duran S, Cantürk N, Cantürk G. Determination of gender by measuring the size of the maxillary sinuses in computerized tomography scans. Surg Radiol Anat 2007;29:9-13.

7. Büyükkoçak B, Paksoy C. Retrospective Evaluation of the Relationshıp Between Volumes of Paranasal Sinuses, Presence of Rhinosinusitis and Nasal Septum Deviations on Cbct Images. Atatürk Üniv Diş Hek Fak.Derg 2019;29:550-5 . 
8. Scarfe WC, Farman AG, Sukovic P. Clinical applications of cone-beam computed tomography in dental practice. J Can Dent Assoc 2006;72:75-80.

9. Ariji Y, Kuroki T, Moriguchi S, Ariji E, Kanda S. Age changes in the volume of the human maxillary sinus: a study using computed tomography. Dentomaxillofac Radiol 1994;23:163-8.

10. Sahlstrand-Johnson $P$, Jannert $M$, Strömbeck $A$, Abul-Kasim K. Computed tomography measurements of different dimensions of maxillary and frontal sinuses. BMC Med Imaging 2011;11:8.

11. Bornstein MM, Ho JKC, Yeung AWK, Tanaka R, Li JQ, Jacobs R. A Retrospective Evaluation of Factors Influencing the Volume of Healthy Maxillary Sinuses Based on CBCT Imaging. Int J Periodontics Restorative Dent 2019;39:187-93.

12. Orhan I, Ormeci T, Aydin S, Altin G, Urger E, Soylu $E$, et al. Morphometric analysis of the maxillary sinus in patients with nasal septum deviation. Eur Arch Otorhinolaryngol 2014;271:727-32.

13. Jun BC, Song SW, Park CS, Lee DH, Cho KJ, Cho $\mathrm{JH}$. The analysis of maxillary sinus aeration according to aging process; volume assessment by 3dimensional reconstruction by high-resolutional CT scanning. Otolaryng Head Neck 2005;132:429-34.

14. Emirzeoglu M, Sahin B, Bilgic S, Celebi M, Uzun A. Volumetric evaluation of the paranasal sinuses in normal subjects using computer tomography images:a stereological study. Auris Nasus Larynx 2007;34:191-5.

15. Rani SU, Rao GV, Kumar DR, Sravya T, Sivaranjani $Y$, Kumar MP. Age and Gender Assessment Through Three-Dimensional Morphometric Analysis of Maxillary Sinus Using Magnetic Resonance Imaging. J Forensic Dent Sci 2017;9:46.

16. Saccucci M, Cipriani F, Carderi S, Di Carlo G, D'Attilio M, Rodolfino D, Festa F, Polimeni A. Gender assessment through three-dimensional analysis of maxillary sinuses by means of cone beam computed tomography. Eur Rev Med Pharmacol Sci 2015;19:185-93.

17. Hettiarachchi PVKS, Gunathilake PMPC, Jayasinghe RM, Fonseka MC, Bandara RMWR, Nanayakkara $C D$, et al. Linear and Volumetric Analysis of Maxillary Sinus Pneumatization in a Sri Lankan Population Using Cone Beam Computer Tomography. Biomed Res Int 2021;2021:6659085.

18. Uchida Y, Goto M, Katsuki T, Akiyoshi T. A cadaveric study of maxillary sinus size as an aid in bone grafting of the maxillary sinus floor. J Oral Maxillofac Surg 1998;56:1158-63.
19. Karakas S, Kavaklı A. Morphometric examination of the paranasal sinuses and mastoid air cells using computed tomography. Ann Saudi Med 2005;25: 41.

20. Kalabalik F, Tarim Ertas E. Investigation of maxillary sinus volume relationships withnasal septal deviation, concha bullosa, and impacted or missing teeth using conebeam computed tomography. Oral Radiol 2019;35:287-95.

21. Kim J, Song SW, Cho J-H, Chang K-H, Jun BC. Comparative study of the pneumatization of the mastoid air cells and paranasal sinuses using three-dimensional reconstruction of computed tomography scans. Surg Radiol Anat 2010;32:5939.

22. Ariji Y, Ariji E, Yoshiura K, Kanda S. Computed tomographic indices for maxillary sinus size in comparison with the sinus volume. Dentomaxillofac Radiol 1996;25:19-24.

23. Schriber M, Bornstein MM, Suter VGA. Is the pneumatisation of the maxillary sinus following tooth loss a reality? A retrospective analysis using cone beam computed tomography and a customised software program. Clin Oral Investig 2019; 23:1349-58.

24. Kawarai $Y$, Fukushima K, Ogawa T, Nishizaki K, Gunduz M, Fujimoto M, Masuda Y. Volume quantification of healthy paranasal cavity by threedimensional CT imaging. Acta Otolaryngol 1999;119:45-9.

25. Fernandes C. Volumetric analysis of maxillary sinuses of Zulu and European crania by helical, multislice computed tomography. J Laryngol Otol 2004;118:877-81.

26. Shrestha B, Shrestha R, Lin T, Lu Y, Lu H, Mai Z, et al. Evaluation of maxillary sinus volume in different craniofacial patterns: a CBCT study. Oral Radiol 2021;Feb 9, doi: 10.1007/s11282-02000506-2, Epub ahead of print.

27. Akbulut N, Kurşun Çakmak EŞ, Bayrak S. Assessment of Maxillary Sinus Changes After Le Fort I Osteotomy Surgery. J Craniofac Surg 2020; 31:e497-e501.

\section{Sorumlu Yazarın Yazışma Adresi}

Dr. Özlem Okumuş

Altınbas University Faculty of Dentistry,

Bakırköy / İstanbul

TIf: (0212) 7094528

e-mail: dtozlemsen@hotmail.com 